\title{
Evidence of an immediate hypersensitivity mechanism in systemic lupus erythematosus
}

\author{
J. EGIDO, M. SÁNCHEZ CRESPO, C. LAHOZ, R. GARCÍA, \\ M. LÓPEZ-TRASCASA, AND L. HERNANDO \\ From the Renal and Immunology Laboratories, Fundación Jiménez Díaz, Madrid
}

SUMMARY In 30 patients with systemic lupus erythematosus the number of circulating basophils was counted in different stages of activity. An inverse correlation was found between the absolute basophil count and anti-DNA antibodies and presumptive circulating immune complexes (as judged by polyethylene glycol precipitation of serum). A positive correlation was found between the absolute basophil count and $\mathrm{C} 3$ or $\mathrm{C} 4$ levels. IgE on the basophil surface was determined by radioimmunoassay in 7 patients. All of them showed a significantly high surface IgE number. When the count of circulating basophils was roughly normal, 5 out of the 6 patients showed a positive basophil degranulation test with native DNA. These results suggest the existence of an anti-DNA specific IgE in lupus patients. Depression of the circulating basophil count may be a useful index of lupus activity.

In the acute serum sickness of rabbits the deposition of immune complexes in the blood-vessel walls involves an increase in vascular permeability induced by the release of vasoactive amines from the platelets. ${ }^{1}$ In these animals the occurrence of the glomerular lesions is particularly associated with antigendependent histamine release from leucocytes ${ }^{2}$; and, on addition of the antigen, basophils sensitised with IgE degranulate and release also a plateletactivating factor (PAF) which aggregates platelets and releases their histamine. ${ }^{3}$ We have recently shown that a diminution of circulating basophils precedes the onset of proteinuria in acute experimental serum sickness; and those rabbits whose basophil count remained normal showed no proteinuria, although they had circulating immune complexes bigger than $19 \mathrm{~S}$ in size. ${ }^{4}$

The role of immediate hypersensitivity in immune complex diseases in man has received little attention. ${ }^{5-8}$ Accordingly, the purpose of this work was to study the implication of the IgE-basophil system in systemic lupus erythematosus, a prototype of immune complex disease in man.

Accepted for publication 22 August 1979.

Correspondence to Dr J. Egido, Laboratorio de Nefrologia, Fundación Jiménez Díaz, Avda. Reyes Católicos 2, Madrid3, Spain.

\section{Materials and methods}

We studied 30 patients with systemic lupus erythematosus, who fulfilled diagnostic clinical criteria of the American Rheumatism Association (ARA) and certain immunological criteria (antinuclear antibodies, anti-DNA antibodies and low serum complement). All patients had renal involvement, shown by renal biopsy, confirmed by light microscopy, immunofluorescence, and in some cases electron microscopy.

\section{STAINING AND COUNTING OF BASOPHILS}

The technique has been described previously in rabbits, ${ }^{9}$ but it has also been found useful for human basophil counting. ${ }^{10}$ Briefly, blood and dye were mixed in a $1 / 10$ proportion and placed in both chambers of a Fuchs-Rosenthal cell. Cells were counted at a magnification of 200 . With this technique basophils were the only cells with stained cytoplasm. The counts were performed by 2 persons, neither of them knowing the clinical situation or the treatment received by the patients. Samples were drawn in the morning. Average absolute basophil counts and percentage of basophils in relation to the total leucocyte count in 47 control subjects were respectively $44 \cdot 5 \pm 15(\mathrm{SD}) / \mathrm{mm}^{3}$ and $0.51 \pm 0.34$ (SD). 
BASOPHIL DEGRANULATION UTILISING

SONICATED DNA

This was undertaken in 6 patients during periods when their basophil count were within normal limits. Since native DNA preparations are viscous, due to their high molecular weight, these are technically unsuitable for degranulation studies. Accordingly, calf thymus DNA (Sigma type 1) at a concentration of $10 \mu \mathrm{g} / \mathrm{ml}$ was sonicated in an ice bath using a Branson W185 sonicator for 40 seconds at maximum output in order to obtain uniform fragments of approximately $10^{6}$ daltons. ${ }^{11}$ This DNA was considered immunologically as native DNA (n-DNA) because in inhibition studies (kindly performed by Dr Picazo) it was totally unreactive with rabbit antisera to denatured DNA. ${ }^{12}$ Whole blood of lupus patients (10 $\mathrm{ml}$ in tubes with heparin) was distributed in $5 \mathrm{ml}$ plastic tubes in $1 \mathrm{ml}$ aliquots. $10 \mu \mathrm{l}$ of a DNA solution in Tris buffer, $0 \cdot 2 \mathrm{M}, \mathrm{pH} 8$, at final concentrations of $0 \cdot 01,0 \cdot 1,1$ and $10 \mu \mathrm{g}$, were added. Two tubes were used as controls. One contained $10 \mu \mathrm{g}$ of unrelated protein (bovine serum albumin) and the other contained neither antigen nor BSA. Tubes were placed at $37^{\circ} \mathrm{C}$ under constant motion for 15 minutes, after which $25 \mu$ of $0.2 \mathrm{M}$ EDTA,

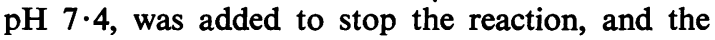
samples were placed in a rotator. Each sample was counted twice and the percentage of basophil degranulation was calculated from the following formula:

$$
\begin{aligned}
& \text { Mean no. of basophils in control samples - mean no. } \\
& \text { basophils in test } \times 100 \text {. } \\
& \text { Mean no. of basophils in control samples }
\end{aligned}
$$

To show that degranulation is calcium-dependent and therefore meaningful, the degranulation test was repeated at optimum DNA concentration in the presence of 5 mM EDTA.

\section{MEASURE OF IGE ON THE BASOPHIL SURFACE}

IgE on the basophil surface was determined on 7 lupus patients at different times by a radioimmunoassay method previously described. ${ }^{13}$ The assay system was based on the capacity of unlabelled immunoglobulin to inhibit the reaction between labelled IgE protein and anti-IgE. ${ }^{14}$

\section{ANTI-DNA ANTIBODY DETERMINATION}

The method used was that of precipitation with $50 \%$ saturated ammonium sulphate, using Escherichia Coli DNA labelled with ${ }^{14} \mathrm{C}$, following Farr's technique. ${ }^{15}$ Binding values under $30 \%$ were considered normal. Sera were heated at $56^{\circ} \mathrm{C}$ for 30 minutes to eliminate nonspecific binding of DNA to C1q. All readings were made in duplicate, and a control serum with a known binding value was included in each test.
POLYETHYLENE GLYCOL (PEG) PRECIPITATION FOR DETECTION OF PRESUMPTIVE

IMMUNE COMPLEXES

Diluted sera were mixed in equal portions with PEG (6000 Merck) solution (borate buffer) at a final PEG concentration of $3.5 \% \%^{16}$ The washed precipitate was dissolved in sodium hydroxide, and the quantity of precipitated protein present was measured by optical density (OD) at $280 \mathrm{~nm}$. The threshold of positivity was taken as $0.130 \mathrm{OD}$, which represents two standard deviations above the mean value for 60 normal controls. The higher values were considered positive, the lower values negative.

\section{COMPLEMENT}

Serum levels of C3, C4, and C3PA were measured by radial immunodiffusion, following Mancini's technique $^{17}$ (Behring Partigen plates).

\section{Results}

CIRCULATING BASOPHIL COUNT AND ITS

RELATIONSHIP WITH ANTI-DNA

ANTIBODIES, SER UM C3, C4, AND C3PA

LEVELS, AND PEG PRECIPITATION

Seventy-one determinations were made in the $\mathbf{3 0}$ lupus patients in different stages of disease activity. The average absolute basophil count and the percentage of basophils in relation to the total leucocytes in lupus patients was of $16.08 \pm 17$ (SD) $/ \mathrm{mm}^{3}$ and $0 \cdot 30 \pm 0 \cdot 23$, significantly low with respect to controls $(\mathrm{P}<0.0005$ and $\mathrm{P}<0.005$ respectively). The basophil count in 67 nonlupus patients with biopsy evidence of glomerulonephritis (minimal changes, mesangiocapillary, membranous, and IgA mesangial glomerulonephritis) has not shown significant differences from the controls (data not shown).

In order to study whether a depressed circulating basophil count represented another sign of lupus activity this parameter was compared with some immunological data generally considered to be 'markers' of activity. Correlations emerged between circulating basophil count and DNA antibodies (expressed as DNA-binding percentage) and serum $\mathrm{C} 3$ and $\mathrm{C} 4$ levels; these relationships are shown in Figs. 1, 2, and 3, respectively. No correlation was found with serum C3PA levels. The relationship between basophil counts and PEG precipitation in 28 patients is shown in Fig. 4. In those patients having a positive precipitation with PEG the average basophil count was $9.42 \pm 6.95(\mathrm{SD}) / \mathrm{mm}^{3}$, while it was $19 \cdot 40 \pm 14 \cdot 87 / \mathrm{mm}^{3}$ in those having it negative $(P<0.001)$. A significant correlation was also found when we compared the average values 
\pm SD of the percentage of basophils in relation to the total leucocytes $(0 \cdot 20 \pm 0 \cdot 14$ versus $0.44 \pm$ $0 \cdot 31$ ) in these 2 groups.

\section{CIRCULATING BASOPHIL SENSITISATION}

WITH RESPECT TO NATIVE DNA

Five out of 6 patients whose basophils were incubated with sonicated DNA showed degranulation greater than $30 \%$ (Fig. 5). Maximal degranulation was reached at $1 \mu \mathrm{g} \mathrm{DNA} / \mathrm{ml}$, except in the patient. ${ }^{1}$ In the majority of the patients the dose-response curves were similar to those obtained by the same technique in patients sensitised against different drugs. ${ }^{10}$ In all patients basophil degranulation was inhibited when the test was performed in the presence of 5 mM EDTA.
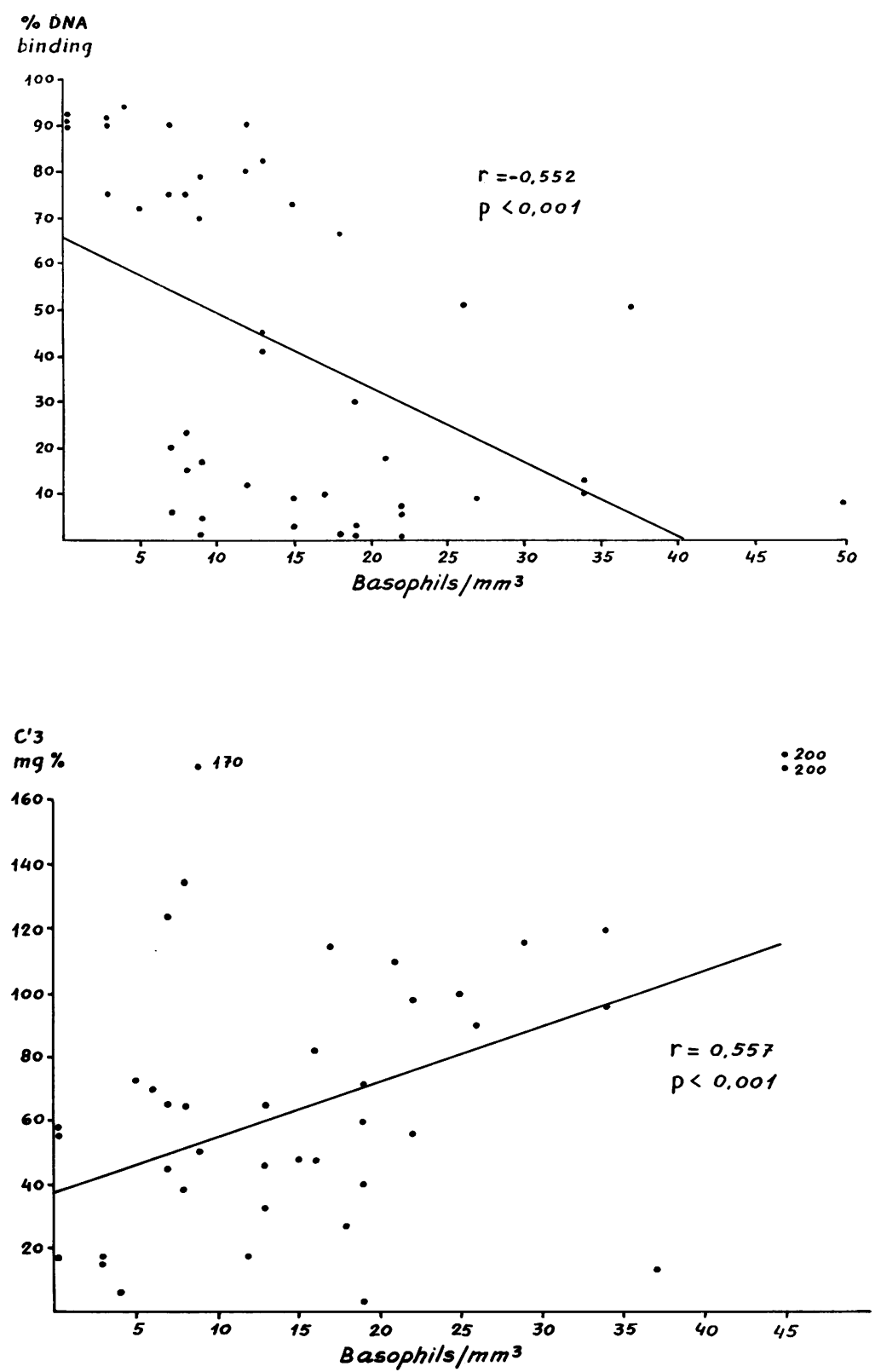

Fig. 1 Correlation between the number of circulating basophils stained by a modified toluidine blue and the DNA antibodies, expressed as DNA-binding percentage.

Fig. 2 Correlation between the number of circulating basophils and serum $C 3$ 


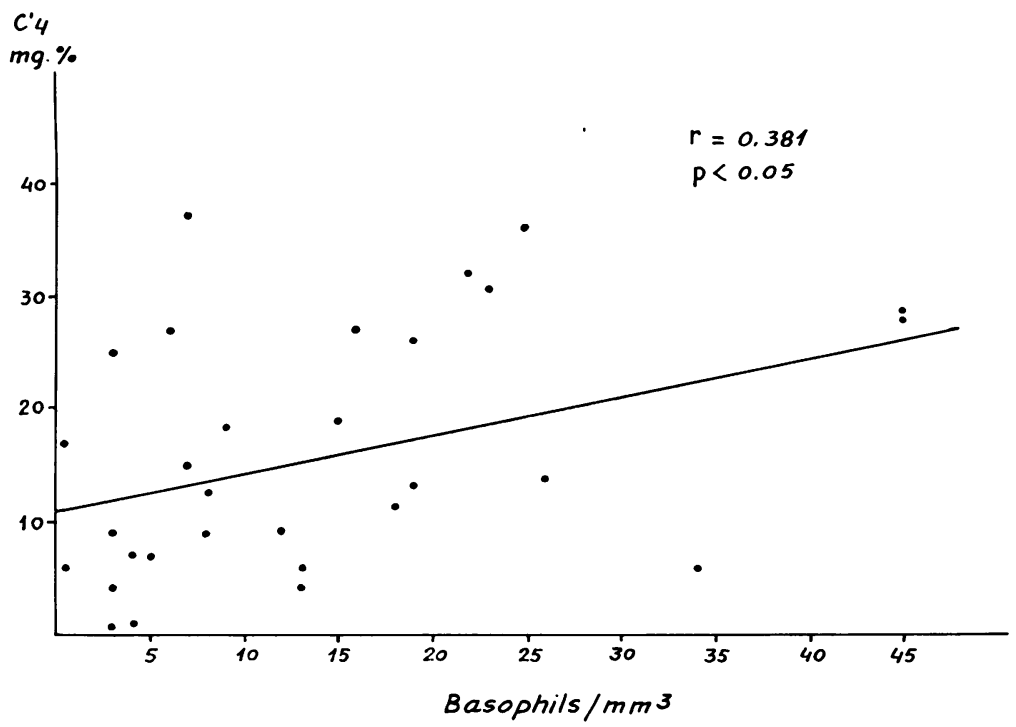

Fig. 3 Correlation between the number of circulating basophils and serum $C 4$.

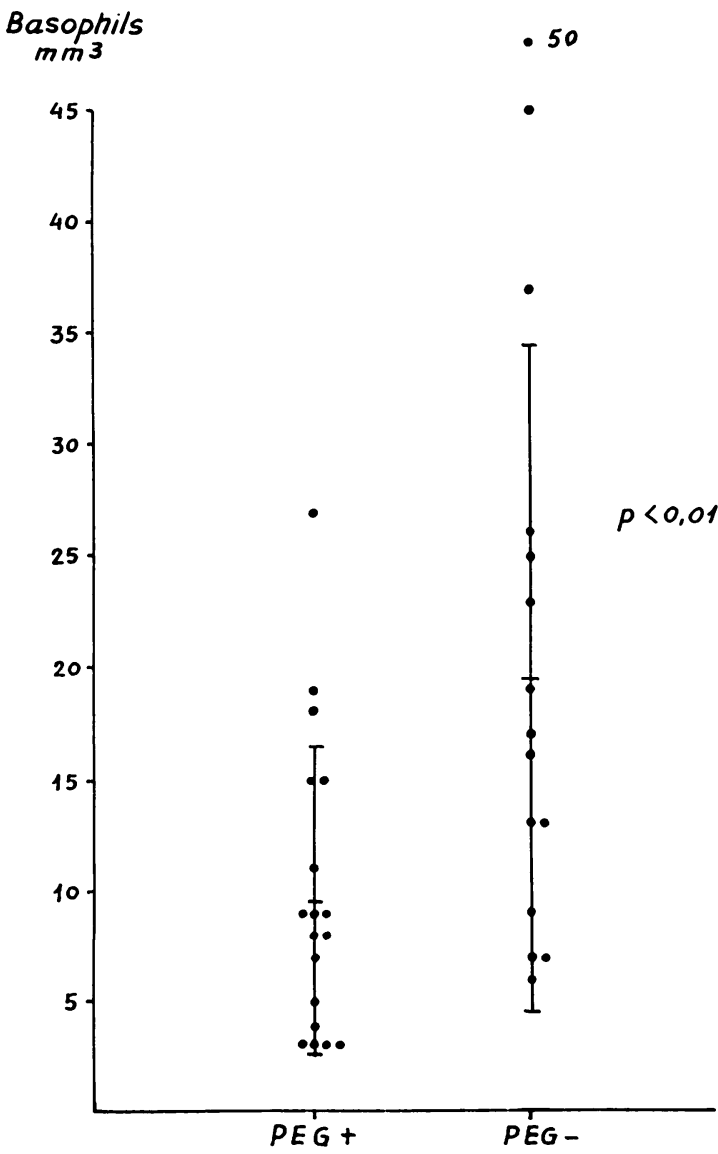

Fig. 4 Relationship between the number of circulating basophils and polyethylene glycol (PEG) precipitation.

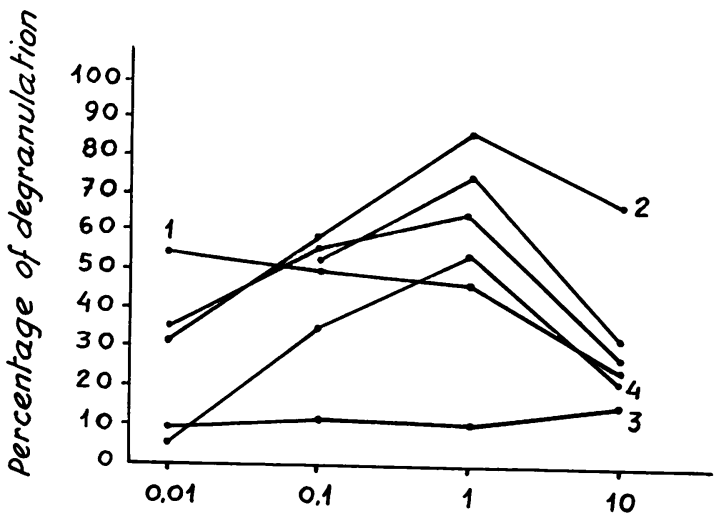

$\mu g \operatorname{m-DNA} / \mathrm{ml}$.

Fig. 5 Basophil degranulation vis-à-vis native DNA. The percentage of degranulation was calculated as commented in 'Material and methods'. In the majority of patients the dose-response curves obtained were typical of basophil degranulation in atopic patients. All degranulations were significantly inhibited when calcium was chelated with EDTA, which proves their specificity. Patients numbered from 1 to 4 represent those in whom the quantitation of IgE molecules on the basophil surface was also performed. Only degranulation above $30 \%$ was considered positive.

\section{NUMBER OF IGE MOLECULES ON THE}

BASOPHIL SURFACE (TABLE 1)

This was calculated from the inhibition data and the standard inhibition curve. ${ }^{13}$ The patients studied had significantly higher basophil surface IgE than the controls $(P<0.0005)$. Three patients had values higher than the method could detect. In 4 patients 
Table 1 Quantitation of IgE molecules on the basophil surface in systemic lupus erythematosus

\begin{tabular}{lllll}
\hline Patients & $\begin{array}{l}\text { Basophils/ } \\
\mathrm{mm}^{3}\end{array}$ & $\begin{array}{l}\text { Percent of } \\
\text { inhibition }\end{array}$ & $\begin{array}{l}\text { Isolated } \\
\text { basophils } \times \\
10^{5}\end{array}$ & $\begin{array}{l}\text { No. of mole- } \\
\text { cules by } \\
\text { basophil }\end{array}$ \\
\hline 1 & 23 & 56 & $0 \cdot 3$ & $>106 *$ \\
2 & - & 55 & $0 \cdot 6$ & $>106$ \\
3 & 13 & 36 & $0 \cdot 6$ & $264 \cdot 000$ \\
4 & 23 & 50 & $0 \cdot 6$ & $660 \cdot 000$ \\
5 & 30 & 49 & $0 \cdot 3$ & $>106$ \\
6 & 13 & 32 & $1 \cdot 0$ & $108 \cdot 900$ \\
7 & 13 & 31 & $0 \cdot 3$ & $330 \cdot 200$ \\
Controls & 23 & 25 & $2 \cdot 6$ & $24 \cdot 100$ \\
8 & 36 & 25 & $2 \cdot 8$ & $25 \cdot 300$ \\
9 & - & 22 & $2 \cdot 2$ & $27 \cdot 100$ \\
10 & 30 & 29 & $3 \cdot 1$ & $28 \cdot 900$ \\
11 & 30 & 31 & $2 \cdot 2$ & $49 \cdot 400$ \\
12 & - & 34 & $2 \cdot 0$ & $54 \cdot 400$ \\
13 & 20 & & &
\end{tabular}

*Values beyond of the method's resolution capacity.

Basophil rich fraction was mixed with the amount of anti-IgE required to bind $50 \%$ of the $125 \mathrm{I}-\mathrm{IgE}$. Incubation was carried out overnight in the cold room. Afterwards the cells were centrifuged and 125I-IgE was added to each supernatant. This mixture was incubated, and soluble immunocomplexes were coprecipitated with the second antibody. ${ }^{13}$

the number of $\operatorname{IgE}$ molecules was determined on the occasion of a degranulation test using sonicated DNA. All but patient 3 showed a significant degranulation, which suggests the existence of DNA specific $\mathrm{IgE}$. There was no overall relationship between the number of basophil associated IgE molecules and the percentage of degranulation, possibly because the basophil cells might have been sensitised against other nuclear antigens. This could also explain the discordance observed in patient 4, though both tests were repeated after an interval of several months and at different stages of clinical activity.

\section{Discussion}

There are few available data on the role of the IgEbasophil system in immune complex disease in man. Robertson et al. ${ }^{7}$ found IgE deposits in the glomeruli in only 5 out of 30 patients with lupus nephropathy; in general, serum IgE levels were in the higher limits of normality. According to these authors neither serum IgE levels nor the degree of proteinuria were related in the intensity of the IgE immunofluorescence of the glomeruli. These results, together with those of Roy et al. ${ }^{5}$ and McPaul et al., ${ }^{6}$ who did not find large amounts of $\operatorname{IgE}$ in the kidney, have contributed to the idea that this immunoglobulin plays no role in these situations.

Normally the $\operatorname{IgE}$ molecules produced in an immune response bind preferentially to membrane receptors of basophils and mast cells, and their presence in serum can be detected only when there is an excess production of $\operatorname{IgE} .^{9}$ In that sense a very high degree of active or passive sensitisation could be achieved without detectable serum IgE-specific levels (in such diverse antigenic systems as peroxidase or bovine serum albumin). ${ }^{9}$ Therefore the presence of detectable IgE antibodies in serum is not a necessary index of basophil sensitisation.

Our results in experimental serum sickness have shown that the IgE basophil system plays a key role in the deposition of circulating immune complexes in the rabbit. In these experiments diminution of circulating basophils, most probably reflecting invivo degranulation, occurred 24-48 hours before the onset of proteinuria. The rabbits whose basophil count remained normal showed no proteinuria, though they had circulating immune complexes bigger than $19 \mathrm{~S}$ in size. The majority of animals with a reduced basophil count gave a positive in-vitro degranulation test with the antigen bovine serum albumin (BSA) during the period immediately following elimination of more than $99 \%$ of the circulating BSA. ${ }^{4}$ We suggest that a similar phenomenon might be occurring in the present series of lupus patients.

Circulating basophil counts in lupus patients were significantly lower than controls. Since many of these patients were not on steroid therapy, which could slightly lower their basophil number, ${ }^{18}$ it was thought that these cells could be sensitised against a range of nuclear antigens, particularly DNA.

A positive basophil degranulation test with nDNA was detected in the majority of the patients. The possibility cannot be ruled out that antibodies to other nuclear antigens might also sensitise basophils. In this context it has recently been shown ${ }^{8}$ that the basophils of patients with rheumatoid arthritis can liberate histamine in the presence of RNA as well as DNA.

The basophils of all lupus patients showed a much greater content of surface IgE than the controls. The lack of a complete correlation with the extent of basophil degranulation induced by DNA could be due in part to sensitisation against other nuclear antigens.

Anti-DNA antibodies in serum of patients with systemic lupus erythematosus have been considered highly specific for the disease and constitute an excellent diagnostic criterion. ${ }^{19}$ Many authors consider that a decrease in serum complement values together with an increase in these antibodies may indicate relapse of disease even before clinical signs and symptomatology. Our results show a correlation between the basophil number and the titre of anti-DNA antibodies and the complement factors C3 and C4. We thus felt that this simple determination could figure among the other immunological criteria in the assessment of disease activity.

In rabbits a good correlation has been shown 
between the antigen-specific basophil degranulation and the release of histamine and platelet activating factor (PAF). ${ }^{3}$ We suggest that lupus patients in activity might in this respect resemble rabbits immunised daily with low doses of antigen. On this basis we suggest further that when an animal or, in this case, a lupus patient is immunised against a specific antigen, IgE antibodies are produced which early sensitise the basophils and mast cells, loaded with potent mediators. Further contact with the antigen will provoke the liberation of these mediators, consequently increasing capillary permeability and the deposition of circulating immune complexes. We suggest that drugs active against basophil degranulation might represent a useful therapeutic adjunct in the management of systemic lupus. Furthermore, depression of circulating basophils may prove to be a useful index of lupus activity.

\section{References}

1 Kniker W T, Cochrane C G. The localization of circulating immune complexes in experimental serum sickness. The role of vasoactive amines and hydrodynamic forces. J Exp Med 1968; 127: 119-136.

2 Henson P M, Cochrane C G. Immune complex disease in rabbits. The role of complement and of a leukocyte dependent release of vasoactive amine from platelets. $J$ Exp Med 1971; 133: 554-571.

8 Benveniste J, Henson P M, Cochrane C G. Leucocytedependent histamine release from rabbit platelets: the role of IgE, basophils and platelet activating factor. J Exp Med 1972; 136: 1356-1377.

4 Benveniste J, Egido J, Gutierrez Millet V (1976). Evidence for the involvement of the IgE basophil system in acute serum sickness of rabbits. Clin Exp Immunol 1976; 26: 449-456.

5 Roy L P, Westberg N C, Michael A F. Nephrotic syndrome: no evidence for a role for IgE. Clin Exp. Immunol 1973; 13: 553-559.
6 McPaul J J, Newcomb R M, Mullins J D, Thompson A L Jr, Lordon R E, Rogers P W. Participations of immunoglobulin E (IgE) in immune mediated glomerulonephritis. Kidney Int 1974; 5: 292-299.

7 Robertson M R, Potter E V, Roberts M L, Patterson R. Immunoglobulin $\mathrm{E}$ in renal disease. Nephron 1976; 16: 256-271.

8 Permin H, Skov P S, Norn S, Juhl F. Autoimmune allergic type 1 reaction in pathogenesis of rheumatoid arthritis. Lancet 1977; 2: 200.

- Benveniste J, Egido J, Gutierrez Millet V, Camussi G. Detection of immediate hypersensitivity in rabbits by direct basophils degranulation. $J$ Allergy Clin Immunol 1977; 59: 271-279.

10 Egido J, Sanchez Crespo M, Garcia Sanchez M, Hernando $\mathrm{L}$, Benveniste J. In vitro basophil degranulation in drugsuspected acute renal failure. Lancet, 1977; 2: 712-713.

11 Doty P, McGill B B, Rice S A. The properties of sonic fragments of Deoxyribose nucleic acid. Proc Nat Acad Sci USA 1958; 44: 432 .

12 Picazo J J, Tan E M. Specificities of antibodies to native DNA. Scand J Rheumatol Suppl 1975; 11 : 35-41.

13 Garcia R, Ureña V, Lahoz C, Ortiz F. Quantitation of IgE on the basophil surface in atopic patients. Int Arch Allergy Appl Immunol 1978: 56: 463-469.

14 Rabellino E, Colon S, Grey H M, Unanue E R. Immunoglobulins on the surface of lymphocytes. I. Distribution and quantitation. $J$ Exp Med 1971 ; 133: 156-167.

15 Minden P, Farr R S. The ammonium sulphate method to measure antigen-binding capacity. In: Weir $\mathbf{D} \mathbf{M}$, ed. Handbook of Experimental Immunology. Oxford: Blackwell 1967; 143.

16 Digeon M, Laver M, Riza J, Bach J F. Detection of circulating immune complexes in human sera by simplified assays with polyethylene glycol $\mathrm{J}$ Immunol Methods 1977; 16: 165-183.

17 Mancini G, Carbonara A O, Heremans J F. Immunochemical quantitation of antigens by simple radial immunodiffusion. Immunochemistry 1965; 2: 235-254.

18 Boseila A W A, Hormonal influence on blood and tissue basophilic granulocytes. Ann NY Acad Sci 1963; 103: 394-408.

19 Pick A I, Levo Y, Weiss C H. The value of anti-DNA antibody titers in the early diagnosis, treatment and follow-up of systemic lupus erythematosus. Isr J Med Sci 1974; 10: 725-730. 